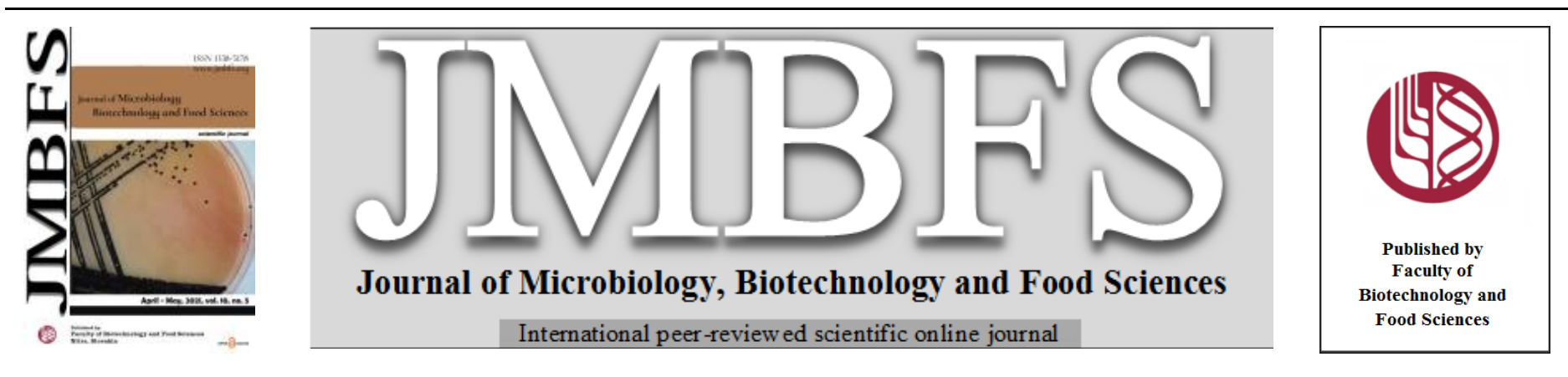

\title{
EFFECT OF DIETARY SUPPLEMENTATION WITH SEAWEED AND POLYPHENOLS MIXTURE ON ANTIOXIDANT STATUS, CONCENTRATION AND MOTILITY OF RABBIT SPERMATOZOA
}

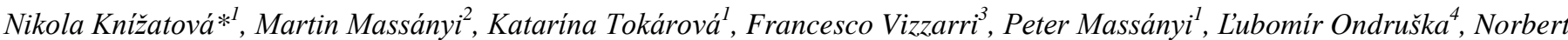 \\ Lukáč ${ }^{1}$
}

Address (es):
${ }^{1}$ Slovak Universit

${ }^{1}$ Slovak University of Agriculture in Nitra, Faculty of Biotechnology and Food Sciences, Department of Animal Physiology, Tr. A. Hlinku 2, 94976 Nitra, Slovak Republic.

${ }^{2}$ Slovak University of Agriculture in Nitra, Faculty of Agrobiology and Food Resources, Department of Animal Husbandry, Tr. A. Hlinku 2, 94976 Nitra, Slovak Republic.

${ }^{3}$ University of Bari Aldo Moro, Department of Agricultural and Environmental Science, Piazza Umberto I, 70121 Bari, Italy.

${ }^{4}$ NPPC - Research Institute for Animal Production Nitra, Hlohovecká 2, 95141 Lužianky, Slovak Republic.

*Corresponding author: nikola.knizatova@gmail.com

https://doi.org/10.15414/jmbfs.2179

\section{ARTICLE INFO}

Received 9. 10. 2019

Revised 11. 11. 2020

Accepted 19. 11. 2020

Published 1. 4. 2021

Regular article OPEN $\partial_{\text {ACCESS }}$

\begin{abstract}
In recent years, many studies have been focused on natural substances that could have effect on health of animals. We investigated effect of extract consisting mainly of polyphenols, brown algae and plant polysaccharides on the reproduction potential of male rabbits (New Zealand white breed) during 60 days long dietary experiment. The rabbits were divided into three groups. Control was fed a basal diet, whereas the second and third group were supplemented with seaweed and polyphenols mixture: $\mathrm{T} 1=0.3 \%$ and $\mathrm{T} 2=0.6 \%$ respectively. We observed that sperm concentration in both experimental groups increased in comparison to the control group. Results of the CASA analysis showed enhanced motility $(\mathrm{C}=85.09 \pm 7.53 \%, \mathrm{~T} 1=87.21 \pm 8.25 \%, \mathrm{~T} 2=89.38 \pm 8.02 \%)$ and progressive motility $(\mathrm{C}=74.28 \pm 12.6 \%, \mathrm{~T} 1=79.07 \pm 13.89 \%, \mathrm{~T} 2=81.28 \pm 11.37 \%)$ in experimental groups supplemented with combination of algae and polyphenols in comparison with the control group. While monitoring ferric reducing ability of plasma (FRAP), we found the highest value in T1 group, changes were insignificat. An increase in GPx activity was measured in experimental groups in comparison with the control group with major difference in $\mathrm{T} 1$ group. In experimental groups, we determined an increase in activity of superoxide dismutase (SOD) in comparison with control group, the difference was significant in $\mathrm{T} 2$ group $(\mathrm{C}=0.26 \pm 0.11 \mathrm{U} / \mathrm{mg} \mathrm{TP}$; $\mathrm{T} 2=0.31 \pm 0.09 \mathrm{U} / \mathrm{mg}$ TP). In conclusion, our studies suggest that dietary supplementation with brown seaweed and plant polyphenols mixture may be potentially useful for enhancement of sperm motility and protection against oxidative stress.
\end{abstract}

Keywords: antioxidant, motility, polyphenols, rabbit, spermatozoa concentration, seaweed

\section{INTRODUCTION}

Oxygen free radicals are molecules forming in aerobic cellular metabolism, containing one or more unpaired electron. Reactive free radicals could bind to different molecules and lead to damage to lipid membranes, nucleic acids and proteins (Aladag et al., 2009). Over the years, plants have served as sources of bioactive compounds for both humans and animals (Pellegrini et al., 2007). Nutritional factors play an important role in the protection against consequences of free radicals (Sikora et al., 2008). Dietary supplementation of antioxidant can enhance the physiological and productive statuses of animals by modifying metabolic processes (Elwan et al., 2019). Consumption of seaweed as a food additive in order to treat diseases have centuries of history in East Asian territories including Japan, China, Vietnam and Korea. In recent decades, due to the extremely rich nutritional values as well as pharmacological properties, the usage of edible seaweed has risen in Western and developing countries (Hong et al., 2007; Hamed et al., 2015; Ruocco et al., 2016).

Although, the production of reactive oxygen species (ROS) is a physiological event in various organs including the testis, various antioxidants have proven helpful in treating infertility of males (Sinclair, 2000). Baker et al. (1996) reported, that antioxidants can be beneficial against the damaging effect of leukocyte-derived ROS on sperm motility due to association of overproduction of ROS with male infertility (Akiyama, 1999).

Despite its importance, the effect of this supplement on reproduction has not been reviewed in the past, therefore we investigated its effect on the reproduction potential of male rabbits The purpose of the present study was to determine the effects of brown seaweed and polyphenols additives on antioxidant status (SOD, GPx, FRAP), concentration and motility of rabbit spermatozoa.

\section{MATERIALS AND METHODS}

\section{Experimental animals and natural extract}

The experiment included 14 males of New Zealand white breed rabbits that have been bred at NPPC-National Agricultural and Food Centre, Research Institute for Animal Production Nitra (Lužianky, Slovak Republic). Management of animals and experimental procedures were managed in accordance with European Community guidelines no. 86/609/EEC. A cycle of $16 \mathrm{~h}$ of light and $8 \mathrm{~h}$ of darkness was maintained throughout the experiment. Temperature was set between $20-24^{\circ} \mathrm{C}$ and humidity level at $65 \%$. In the experiment, which lasted for 60 days, adult males rabbits were used as an excellent model for assessing the effects of toxic agents on semen quality and fertility. The dietary supplement was analyzed and the composition of the polyphenols profile is reported in Table 1. During our experiments, animals were divided into 3 homogeneous groups $(18.5 \pm 1.5$ months old; $4.90 \pm 0.87 \mathrm{~kg})$. Control group $(\mathrm{C}, \mathrm{n}=8)$ rabbits were fed by commercial feed. Rabbits from first experimental group (T1, $n=8$ ) were fed by feed supplemented with $0.3 \%$ of natural extract mixture and animals from second experimental group $(\mathrm{T} 2, \mathrm{n}=8)$ were fed by feed supplemented with $0.6 \%$ of natural extract mixture. Natural extract mixture was provided by Lombarda Trading (Italy) and polyphenol content was measured using HPLC.

\section{Semen sampling and analysis}

The semen samples were collected on 60th day using artificial vagina. The obtained semen samples were diluted with physiological solution (1:5). Each of prepared samples were evaluated using a Computer Assisted Semen Analyzer (CASA) system - Sperm Vision (Minitub, Tiefenbach, Germany) equipped with 
a microscope (Olympus BX 51, Japan) to assess the spermatozoa motility. Each sample was placed into Makler Counting Chamber. We analysed spermatozoa concentration, total motile spermatozoa and progressive motile spermatozoa using the rabbit specific set up. SOD activity as well as activity of GPx were analysed by RANSOD assay (Randox Laboratories, Crumblin, Great Britain). FRAP assessment was guided by the original method described by Benzie and Strain (1996).

\section{Statistical analysis}

All the data was expressed as mean \pm standard deviation (SD). The means of various parameters of control and experimental animals were compared using ANOVA \& Tukey test for statistical significance in GraphPad Prism. $P \leq 0.05$ was considered to be statistically significant.

Table 1 Polyphenols content in the natural extract supplement.

\begin{tabular}{ll}
\hline Neochlorogenic acid $(\mathrm{mg} / \mathrm{kg})$ & 7979.23 \\
\hline Elaigic acid $(\mathrm{mg} / \mathrm{kg})$ & 2440.88 \\
\hline Syringic acid $(\mathrm{mg} / \mathrm{kg})$ & 1059.79 \\
\hline Cynaroside $(\mathrm{mg} / \mathrm{kg})$ & 566.72 \\
\hline Rutin $(\mathrm{mg} / \mathrm{kg})$ & 272.37 \\
\hline Rosmarinic acid $(\mathrm{mg} / \mathrm{kg})$ & 126.54 \\
\hline Trans-sinapic acid $(\mathrm{mg} / \mathrm{kg})$ & 105.54 \\
\hline Myricetin $(\mathrm{mg} / \mathrm{kg})$ & 53.88 \\
\hline Chlorogenic acid $(\mathrm{mg} / \mathrm{kg})$ & 21.45 \\
\hline Protocatechuic acid $(\mathrm{mg} / \mathrm{kg})$ & $<\mathrm{LOD}$ \\
\hline Vitexin $(\mathrm{mg} / \mathrm{kg})$ & $<\mathrm{LOD}$ \\
\hline Trans p-coumaric acid $(\mathrm{mg} / \mathrm{kg})$ & $<\mathrm{LOD}$ \\
\hline Trans-ferulic acid $(\mathrm{mg} / \mathrm{kg})$ & $<\mathrm{LOD}$ \\
\hline Resveratrol $(\mathrm{mg} / \mathrm{kg})$ & $<\mathrm{LOD}$ \\
\hline Daidzein $(\mathrm{mg} / \mathrm{kg})$ & $<\mathrm{LOD}$ \\
\hline Quercetin $(\mathrm{mg} / \mathrm{kg})$ & $<\mathrm{LOD}$ \\
\hline Apigenin $(\mathrm{mg} / \mathrm{kg})$ & $<\mathrm{LOD}$ \\
\hline Kaempferol $(\mathrm{mg} / \mathrm{kg})$ & $<\mathrm{LOD}$ \\
\hline
\end{tabular}

Legend: <LOD - below LOD, $\mathrm{mg} / \mathrm{kg}$ - milligram/kilogram

\section{RESULTS}

In this study we analysed antioxidant status, concentration and motility of rabbit spermatozoa following oral administration of polyphenols and seaweed mixture at different doses (groups T1, T2) and compared them against the control group without any addition (C). The results of the analysis are shown in Figures $1-6$. As seen in Figure 1, administration of seaweed and polyphenols mixture in individual doses (T1 - received $0.3 \%, \mathrm{~T} 2$ - received $0.6 \%$ ) resulted in increase of enzyme activity in both experimental groups, increase was significant in T2 group $(\mathrm{P}<0.05)$ when compared to the control group.

\section{SOD (U/mg TP)}

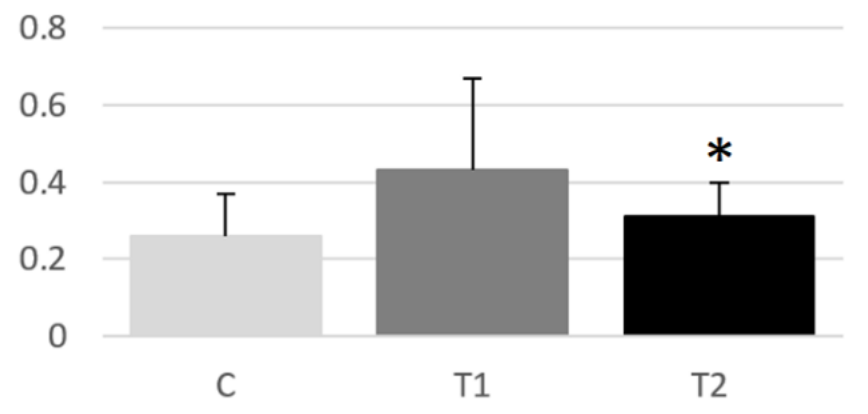

Figure 1 The values of the activity of superoxide dismutase $(\mathrm{C}=0.26 \pm 0.11$ $\mathrm{U} / \mathrm{mg}$ of total protein; $\mathrm{T} 1=0.43 \pm 0.24 \mathrm{U} / \mathrm{mg}$ of total protein, $\quad \mathrm{T} 2=0.31 \pm 0.09$ $\mathrm{U} / \mathrm{mg}$ of total protein)

Legend: Groups of rabbit with doses of seaweed and polyphenols mix: $\mathrm{C}-0 \%$; $11-0.3 \%$; $\mathrm{T} 2-0.6 \%$; *statistical significant at $\mathrm{P}<0.05$ in comparison to control group

Figure 2 shows the values of the activity of glutathione peroxidase. Administration of brown seaweed and polyphenols mix in individual doses (T1 $0.3 \%, \mathrm{~T} 2-0.6 \%)$ resulted into increasing trend of enzyme activity in both experimental groups.

\section{GPx (U/g TP)}

100

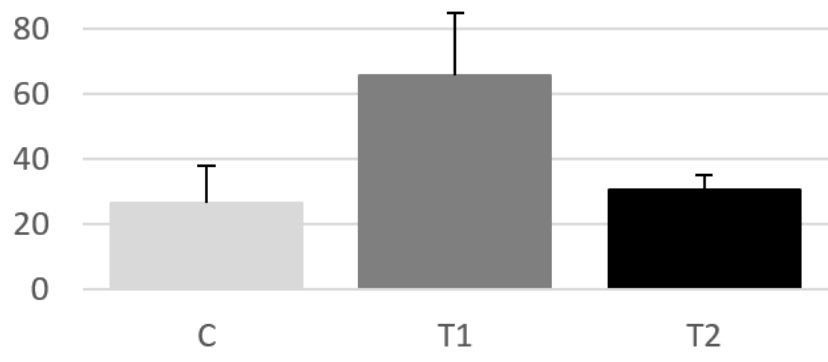

Figure 2 The values of the activity of glutathione peroxidase $(\mathrm{C}=26.6 \pm 11.25$ $\mathrm{U} / \mathrm{g}$ of total protein; $\mathrm{T} 1=65.58 \pm 19.31 \mathrm{U} / \mathrm{g}$ of total protein; $\quad \mathrm{T} 2=30.53 \pm 4.53$ $\mathrm{U} / \mathrm{g}$ of total protein)

Legend: Groups of rabbit with doses of seaweed and polyphenols mix: C $-0 \%$; $11-0.3 \%$; $\mathrm{T} 2-0.6 \%$

As Figure 3 shows, the administration of seaweed and polyphenols mix in individual doses (T1 - received $0.3 \%$, T2 - received $0.6 \%$ ) resulted in insignificant increase of FRAP in both experimental groups.

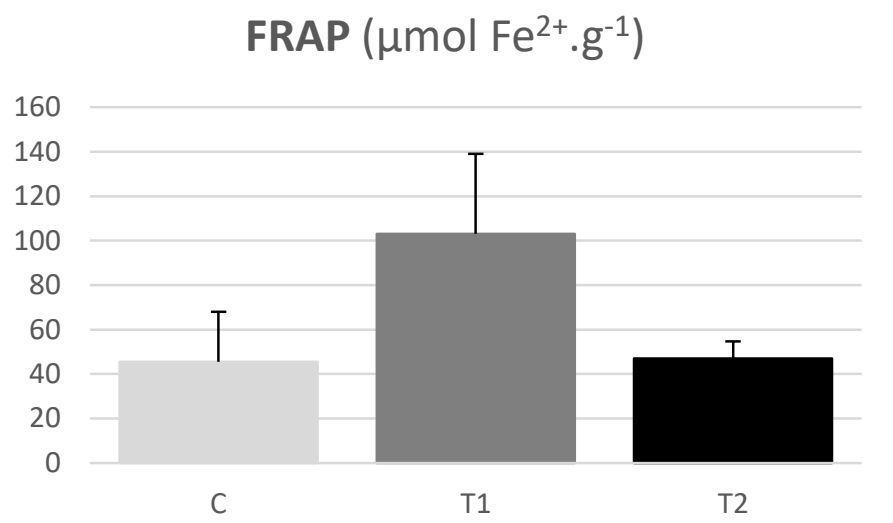

Figure 3 The values of the ferric reducing activity of plasma $(C=45.46 \pm 22.51$; $\mathrm{T} 1=103.00 \pm 36.10 ; \mathrm{T} 2=47.11 \pm 7.53$ )

Legend: Groups of rabbit with doses of seaweed and polyphenols mix: $\mathrm{C}-0 \%$; $\mathrm{T} 1-0.3 \%$; $\mathrm{T} 2-0.6 \%$

As seen in Figure 4, administration of seaweed and polyphenols mixture in individual doses (T1 - received $0.3 \%$, T2 - received $0.6 \%$ ) resulted in nonsignificant increasing trend of sperm concentration.

\section{Concentration $\left(10^{6} \cdot \mathrm{ml}^{-1}\right)$}

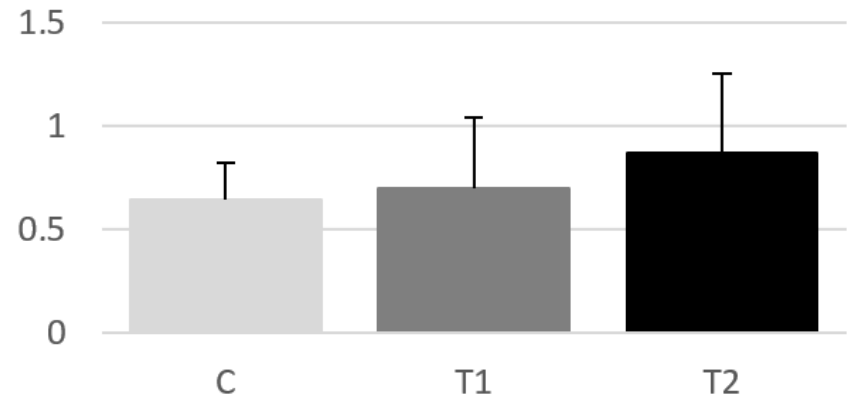

Figure 4 The values of the spermatozoa concentration $(\mathrm{C}=0.647 \pm 0.16$; $\mathrm{T} 1=$ $0.699 \pm 0.35 ; \mathrm{T} 2=0.871 \pm 0.39$ )

Legend: Groups of rabbit with doses of seaweed and polyphenols mix: $\mathrm{C}-0 \%$; $\mathrm{T} 1-0.3 \%$; $\mathrm{T} 2-0.6 \%$

Data obtained from CASA analysis are shown in Figure 5, which shows the values of sperm motility. Administration of brown seaweed and polyphenols mix in individual doses $(\mathrm{T} 1-0.3 \%, \mathrm{~T} 2-0.6 \%)$ resulted in significant increase of motility in T1 group and nonsignificant increase in T2 group in comparison with the control group. 


\section{Motility (\%)}

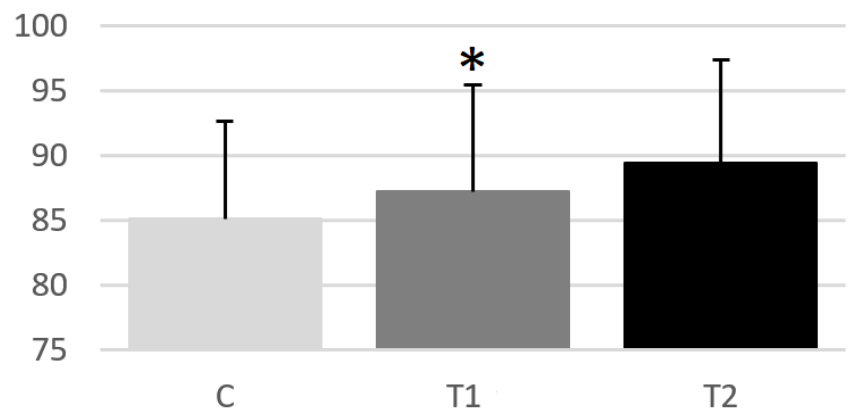

Figure 5 The values of the sperm motility $(\mathrm{C}=85.09 \pm 7.53 \%$, $\mathrm{T} 1=$ $87.21 \pm 8.25 \%, \mathrm{~T} 2=89.38 \pm 8.02 \%)$

Legend: Groups of rabbit with doses of seaweed and polyphenols mix: $\mathrm{C}-0 \%$; $\mathrm{T} 1-0.3 \%$; $\mathrm{T} 2-0.6 \%$; *statistical significant at $\mathrm{P}<0.05$ in comparison to control group

Data obtained from CASA analysis are shown in Figure 6. Administration of seaweed and polyphenols mixture in individual doses (T1 - received $0.3 \%$, T2 received $0.6 \%)$ resulted in nonsignificant $(\mathrm{p}>0.05)$ increasing trend of progressive motility in both experimental groups.

\section{Progressive motility (\%)}

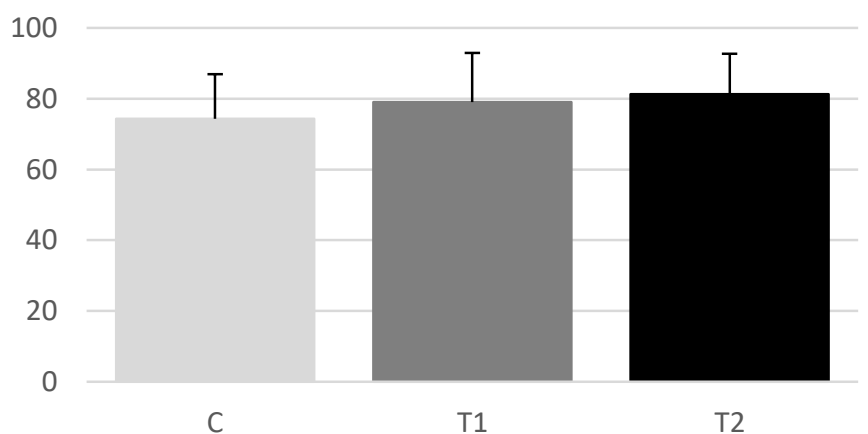

Figure 6 The values of progressive motility $(\mathrm{C}=74.28 \pm 12.6 \%$, $\mathrm{T} 1=$ $79.07 \pm 13.89 \%, \mathrm{~T} 2=81.28 \pm 11.37 \%)$

Legend: Groups of rabbit with doses of seaweed and polyphenols mix: C - 0\%; T1 - 0.3\%; $\mathrm{T} 2-0.6 \%$

\section{DISCUSSION}

To our knowledge, the present study is the first to report of the antioxidant effect of brown seaweed and plant polyphenols mixture on male reproductive system. Our experiment indicates, that application this mixture caused an increase of selected reproductive parameters (sperm concentration, motility, progressive motility), as well as antioxidant parameters (SOD, GPx, FRAP). Our findings demonstrated, that mixture of brown seaweed and plant polyphenols might be capable of protecting spermatozoa against oxidative stress, since rabbi spermatozoa in treated groups exhibited increase in concentration, motility and progressive motility in comparison with the control group.

Natural antioxidants-rich diets are capable of reducing the risk of some diseases induced by free radical generation. A significant amount of antioxidants in a diet is able to encourage immunological processes and elevate the defensive abilities of the cell (Sikora et al., 2008). The presence of phenolic compounds and flavonoids in the diet provides health benefits, however these benefits of phenolic compounds depend on their consumption and bioavailability. Phenolic compounds display a wide range of biological and chemical activities, including excellent scavenging activities (Rodríguez et al., 2009). Our research might support this finding as all of parameters monitored in our experiment slightly increased.

Sharma and Agarwal (1996) reported that seminal plasma confers some protection against ROS damage because it contains enzymes that scavenge ROS such as SOD and GPx. Sperm membranes must be protected by a highly effective antioxidant system to prevent the peroxidative damage. The antioxidant system in semen includes enzymes such as glutathione GPx, SOD and catalase (Partyka et al., 2012). The first line of defence against the superoxide radicals are the SODs. Highly toxic hydrogen peroxide formed during superoxide dismutation is removed by GPX and catalase (Delamirande et Gagnon, 1995; Griveau et al., 1995). The present results showed an increase $(P>0.05)$ in SOD and GPx levels as well as FRAP in seminal plasma of animals treated with natural mixture
(Figures 1-3). Pavin et al. (2018) reported, that supplementation with extract of Tribulus terrestris, which is high in antioxidants caused an increase in SOD and GPx levels.

Figures 4-6 showed a slight increase in sperm concentration, motility and progressive motility. Similar results were found by Brzezinska-Slebodzinskaet al. (1995), Geva et al. (1996), Hsu et al. (1998), Surai et al. (1998), and Akiyama (1999), who reported antioxidant supplementation (vitamin E, vitamin $\mathrm{C}$, selenium) reduced ROS generation and improved semen quality. The beneficial effect in improving fertilization rate was possibly due to a reduction in lipid peroxidation potential. Yousef et al. (2003) investigated effects of ascorbic acid and vitamin E supplementation on semen quality of male rabbits. According to their results, antioxidant supplementation led to improvement in ejaculate volume, total motile sperm, sperm motility index and sperm concentration. These results are in agreement with our results, however Weng et al. (2018) reported that supplementation with Astragalus polysaccharides did not affect sperm motility.

\section{CONCLUSION}

The present study is the first to investigate effect of dietary supplementation with seaweed and polyphenols mixture on antioxidant status, concentration and motility of rabbit spermatozoa. In conclusion, this experiment indicates, that application of brown seaweed and plant polyphenols mixture caused an increasing trend of selected male reproductive parameters (sperm concentration, motility, progressive motility) as well as antioxidant parameters (SOD, GPx, FRAP), which points to the positive effect of this mixture added to feed Considering that this is a pilot study, we may suggest further studies in order to understand effects of this mixture on male reproduction, other organ systems, and different animal species, as well as the mechanism of this extract in relation to its potential beneficial effects. This study indicates the practical potential of using seaweed and polyphenols mixture as an dietary supplement.

Acknowledgements: The present work was developed with the support of the Research Centre AgoBioTech built under the project Building Research Centre, AgroBioTech ITMS 26220220180 and the VEGA 1/0539/18, VEGA1/0392/20, VEGA 1/0038/19, APVV-15-0543, APVV-16-0289 and APVV-15-0544. This publication was supported by the Operational program Integrated Infrastructure within the project: Creation of nuclear herds of dairy cattle with a requirement for high health status through the use of genomic selection, innovative biotechnological methods, and optimal management of breeding, NUKLEUS 313011V387, cofinanced by the Euruopean Regional Development Fund.

\section{REFERENCES}

AKIYAMA, M. (1999). In vivo scavenging effect of ethylcysteine on reactive oxygen species in human semen. Nippon Hinyokika Gakkai Zasshi, 90(3), 421428.

ALADAG, I., EYIBILEN, A., GUVEN, M., ATIS, O. \& ERKORKMAZ, U. 2009. Role of oxidative stress in hearing impairment in patients with type two diabetes mellitus. The Journal of Laryngology \& Otology, 123(9), 957-963. https://doi.org/10.1017/S0022215109004502.

ASADI, N., BAHMANI, M., KHERADMAND, A. \& RAFIEIAN-KOPAEI, M (2017). The Impact of Oxidative Stress on Testicular Function and the Role of Antioxidants in Improving It: A Review. Journal of Clinical and Diagnostic Research, $\quad$ 11(5), IE01-IE05. https://doi.org/10.7860/JCDR/2017/23927.9886.

BAKER, H.W., BRINDLE J., IRVINE D.S. \& AITKEN R.J. (1996). Protective effect of antioxidants on the impairment of sperm motility by activated polymorphonuclear leukocytes. Fertilily and Sterility, 65(2), 411-419.

BENZIE, F. F. I. \& STRAIN, J. J. (1996). The ferris reducing ability of plasma (FRAP) as a measure of „Antioxidant power": The FRAP assay. Analytical Biochemistry, 239, 70-76.

BRZEZINSKA-SLEBODZINSKA, E., SLEBODZINSKI, A.B., PIETRAS, B. \& WIECZOREK, G. (1995). Antioxidant effect of Vitamin $\mathbf{E}$ and glutathione on lipid peroxidation in boar semen plasma. Biological Trace Element Research, 47, 69-74.

DELAMIRANDE, E. \& GAGNON C. (1995). Impact of reactive oxygen species on spermatozoa - a balancing act between beneficial and detrimental effects Human Reproduction, 10, 15-21

ELWAN, A. M. H., DAWOOD, D. H., EL-SHAFEI, S. M. A.E., EL-RAHMAN, A. A. E. A., ABDEL-LATIF S. A., MOHANY, M., ALQAHTANI, F., ALQAHTANI, S., \& AL-REJAIE, S. S. (2019) The Potential Role of Citrus limon Powder as a Natural Feed Supplement to Boost the Productive Performance, Antioxidant Status, and Blood Biochemistry of Growing Rabbits. Animals (Basel), 9(7), 426. https://doi.org/10.3390/ani9070426.

GEVA, E., BARTOOV, B., ZABLUDOVSKY, N., LESSING, J.B., LERNERGEVA, L. \& AMIT, A. (1996). The effect of antioxidant treatment on human spermatozoa and fertilization rate in an in vitro fertilization program. Fertilily and Sterility, 66, 430-434. 
GRIVEAU, J. F., RENARD, P. \& LELANNOU, D. (1995). Superoxide anion production by human spermatozoa as a part of the ionophore-induced acrosome reaction process. International Journal of Andrology, 18, 67-74.

HAMED, I., ÖZOGUL, F., ÖZOGUL, Y. \& REGENSTEIN, J. M. (2015)

Marine bioactive compounds and their health benefits: a review. Comprehensive Reviews in Food Science and Food Safety, 14(4), 446-465. https://doi.org/10.1111/1541-4337.12136.

HALLIWELL, B. (2006). Polyphenols: Antioxidant Treats for Healthy or Covert Toxins?. Journal of the Science of Food and Agriculture, 86, 1992-1995. https://doi.org/10.1002/jsfa.2612.

HSU, P.C., LIU, M.Y., HSU, C.C., CHEN, L.Y. \& GUO, Y.L. (1998). Effects of Vitamin $\mathrm{E}$ and/or $\mathrm{C}$ on reactive oxygen species-related lead toxicity in the rat sperm. Toxicology, 128(3), 169-179.

KIM, J.G. \& PARTHASARATHY. S. (1998). Oxidation and the spermatozoa Seminars in Reproductive Endocrinology, 16(4), 235-239.

HONG, D. D., HIEN, H. M. \& SON P. N. (2007). Effect of irradiation on the protein profile, protein content, and quality of agar from Gracilaria asiatica Zhang et Xia (Rhodophyta). Journal of Applied Phycology, 19(6), 809-815. https://doi.org/10.1007/s10811-007-9213-4.

PARTYKA, A., ŁUKASZEWICZ, E. \& NIZANSKI W. (2012). Lipid peroxidation and antioxidant enzymes activity in avian semen. Animal $\begin{array}{lll}\text { Reproduction } & \text { Science, } & 134,\end{array}$ https://doi.org/10.1016/j.anireprosci.2012.07.007.

LIU, H., SUN, Y., ZHAO, J., DONG, W. \& YANG, G. (2019). Effect of Zinc Supplementation on Semen Quality, Sperm Antioxidant Ability, and Seminal and Blood Plasma Mineral Profiles in Cashmere Goats. Biological Trace Element Research. https://doi.org/10.1007/s12011-019-01933-x.

PELlEGRINI, N. M., SERAFINI, B. O., COLOMBI, D. D., RIO, S. T., SALVOTORE, R. A. \& BIONCHI W. O. (2003). Total antioxidant capacity of plant foods, beverages and oils consumed in italy assessed by three different in vitro assays. The Journal of Nutrition, 133(9), 2812-2819. https://doi.org/10.1093/jn/133.9.2812.

RODRÍGUEZ, H., GÓMEZ-CORDOVÉS, C., CURIEL, J.A., MANCHEÑO, J.M., LANDETE, J.M., RIVAS, B.D.L. \& MUÑOZ, R. (2009). Food phenolics and lactic acid bacteria. International Journal of Food Microbiology, 132, 79-90. https://doi.org/10.1016/j.ijfoodmicro.2009.03.025.

RUOCCO, N., COSTANTINI, S., GUARINIELlO, S. \& COSTANTINI, M. (2016). Polysaccharides from the marine environment with pharmacological, cosmeceutical and nutraceutical potential. Molecules, 21(5), p. 551 https://doi.org/10.3390/molecules21050551.

SHARMA, R.K. \& AGARWAL A. (1996). Role of reactive oxygen species in male infertility. Urology, 48(6), 835-850.

SIKORA, E., EWA, C. \& TOPOLSKA, K. (2008). The sources of natural antioxidants. Acta Scientiarum Polonorum Technologia Alimentaria, 7, 5-17.

SINCLAIR, S. (2000). Male infertility: nutritional and environmental considerations. Alternative Medicine Review, 5(1), 28-38.

SURAI, P., KOSTJUK, I., WISHART, G., MACPHERSON, A., SPEAKE, B. NOBLE, R., IONOV, I. \& KUTZ, E. (1998). Effect of Vitamin E and selenium supplementation of cockerel diets on glutathione peroxidase activity and lipid peroxidation susceptibility in sperm, testes, and liver. Biological Trace Element Research, 64(1-3), 119-132.

YOUSEF, I. M., ABDALLAH, A. G. \& KAMEL, I. K. (2003). Effect of ascorbic acid and Vitamin E supplementation on semen quality and biochemical parameters of male rabbits. Animal Reproduction Science, 76(1-2), 99-111. https://doi.org/10.1016/S0378-4320(02)00226-9.

WENG, X., CAI, M., ZHANG, Y., LIU, Y., GAO, Z., SONG, J. \& LIU, Z (2018). Effect of Astragalus polysaccharide addition to thawed boar sperm on in vitro fertilization and embryo development. Theriogenology, 121, 21-26. https://doi.org/10.1016/j.theriogenology.2018.07.030. 